\title{
Floral biology of Schismatoglottis baangongensis (Araceae) in West Sarawak, Borneo
}

\author{
Yin Ch. Hoe ${ }^{1,2} \cdot$ Sin Y. Wong ${ }^{1,3}$
}

Received: 13 March 2016/Accepted: 25 June 2016

(c) Springer-Verlag Wien 2016

\begin{abstract}
The flowering mechanism, visiting insect activities, reproductive system, and floral scent composition of Schismatoglottis baangongensis a Northwest Bornean locally endemic limestone-restricted protogynous mesophyte were investigated. Anthesis started at dawn and lasted ca $29 \mathrm{~h}$. Fruit set for open pollination $(93 \%)$ and restricted access pollination $(88 \%)$ were high. Colocasiomyia (Diptera, Drosophilidae) and Cycreon (Coleoptera, Hydrophilidae) were the main pollinators. Colocasiomyia flies present in much higher numbers than Cycreon beetles individually carried significantly less pollen load. Chaloenus (Chrysomelidae, Galerucinae) was inadvertent pollinators, and Atheta (Coleoptera, Staphylinidae) passive visitors. Pollen transferal between dissimilar insect genera (Colocasiomyia and Chaloenus) is reported for the first time. Low pollen/ovule ratio of $S$. baangongensis indicated an efficient pollination mechanism. Ester compound class floral odours, especially the dominant compounds 3-butenoic acid, 3-methyl-, methyl ester, were decisive in attracting pollinators. The spadix appendix of $S$.
\end{abstract}

Handling editor: Marlies Sazima.

Electronic supplementary material The online version of this article (doi:10.1007/s00606-016-1329-z) contains supplementary material, which is available to authorized users.

Sin Y. Wong

sywong@unimas.my

1 Department of Plant Science and Environmental Ecology, Faculty of Resource Science and Technology, Universiti Malaysia Sarawak, 94300 Samarahan, Sarawak, Malaysia

2 Tunku Abdul Rahman University College, Johor Branch Campus, 85000 Segamat, Johor, Malaysia

3 Harvard University Herbaria, 22 Divinity Avenue, Cambridge, MA 02138, USA baangongensis was the main olfactory body although the spathe was detected to release an additional $\mathrm{N}$-containing compound, an indole. An increase in the total amount of floral scent from the pistillate flower zone during pistillate phase of anthesis from Period I (06:00-08:00 h) to Period II (08:00-10:00 h) was postulated to detain insects in the lower chamber of the inflorescence.

Keywords Ester compound class · Floral volatiles · Pollen load $\cdot$ Pollination

\section{Introduction}

Schismatoglottis Zoll. \& Moritzi is the largest genus in Tribe Schismatoglottideae, with about 120 described species out of an estimated 250 species (Boyce and Croat 2010; Hay and Yuzammi 2000; Boyce et al. 2010; Wong et al. 2010; Wong 2013). The type of the genus, Schismatoglottis calyptrata (Roxb.) Zoll. \& Moritzi, is currently circumscribed as a polymorphic species occurring from central and eastern Indo-Malaya to northern Australasia (New Guinea and the Bismark Archipelago) as far east as Vanuatu (Hay and Yuzammi 2000; Wong 2012). Research in Sunda, however, is revealing a more intricate taxonomic situation with the existence of numerous locally endemic and geologically specialized species, the majority undescribed (Wong et al. unpublished data). Alongside a molecular analysis of species' relationships (Low et al. unpublished data), the opportunity to investigate pollination system was pursued: Schismatoglottis baangongensis S.Y.Wong, Y.C.Hoe \& P.C.Boyce, a recently published species (Wong et al. 2016), is the subject of this study.

Flowering biology and pollination investigations for Schismatoglottideae are limited to a few studies (Hotta 